\title{
International Carbon Market and India'a Position
}

\author{
* Prof. Mahananda Nashi
}

\section{Introduction}

The concept of carbon market came into existence as a result of awareness of the need for controlling the greenhouse gas emissions. Climate change due to greenhouse gas emissions will increase the severity and frequency of storms, droughts, floods, forest fires, heat waves, extinction of species, spread of diseases etc. The impact of these hazards is being already felt and hence world leaders entered into an international treaty - the Kyoto Protocol - to place legally binding caps on greenhouse gas emissions by industry in developed countries. The Kyoto Protocol, which is linked to the United Nations Framework Convention on Climate Change, has developed three mechanisms for carbon trading. The Clean Development Mechanism, one among them, is a flexible mechanism which enables an entity in a developing country like India, to effect greenhouse gas emission reductions, have them verified by the Designated Operating Entities, and sell the Certified Emission Reductions/carbon credits so achieved by effecting emission reductions, to the developed nations, as a compliance tool to reach their emission targets. The rationale of this mechanism is that bringing about greenhouse gas emission reductions in developing countries is more cost effective than by doing so in developed countries. The Clean Development Mechanism has promoted foreign investments and latest clean technology transfers to developing countries and also their sustainable development and emission reductions by participating in international carbon market.

The present study focuses on:

- Carbon trading and the United Nations Framework Convention on Climate Change (UNFCCC)

- The Kyoto Protocol and Clean Development Mechanism (CMD)

- Trading units in the carbon market - RMU, ERU and CERs.
- Designated National Authority for Clean Development Mechanism and Climate Exchanges

- India's position in international carbon market: A comparative study:

- Methodology and data collection

- Total and per capita carbon emissions

- Cost of greenhouse gas emission reductions

- Registered project activities by host party (select developing countries)

- CERs issued by host party

- Expected average annual CERs from registered projects by host party

- Findings and suggestions

Carbon trading is basically buying and selling of Carbon Credits. Carbon Credits are the emission reduction certificates/emission trading units assigned to the clean energy project sponsors who reduce carbon dioxide emissions. One Carbon Credit is equivalent to one tonne reduction of carbon dioxide or its corresponding greenhouse gas (GHG). For example, a hydroelectric power plant avoids the emission of 30,000 tonnes of carbon dioxide equivalent per year, since it avoids burning coal in a coal-powered plant to produce the same quantity of electricity. The project sponsor is assigned 30,000 carbon credits each accounting for one tonne of avoided carbon dioxide equivalent. The project sponsor can sell these carbon credits to help finance his project.

Carbon credits are issued by the United Nations Framework Convention on Climate Change (UNFCCC) under the Clean Development Mechanism (CDM) scheme of the Kyoto Protocol.

\footnotetext{
* Selection Grade Lecturer, Department of Commerce, KLE society's Nijalingappa College, Rajajinagar, Bangalore email : nandanashi@rediffmail.com (M) : 9980129807
} 


\section{The Kyoto Protocol:}

The Kyoto Protocol is an international agreement linked to the United Nations Framework Convention on Climate Change. The major feature of the Kyoto Protocol is that it sets binding target for 37 industrialized countries and the European community (Annex B Countries) for reducing Greenhouse Gas emissions to an average five percent against 1990 levels over the five - year period 2008-2012.

The Kyoto Protocol was adopted in Kyoto, Japan, on 11 December 1997 and entered into force on 16 February 2005. Almost all industrialized nations and some countries with developing economies like India, China, Brazil and others, have ratified the Kyoto Protocol to reduce pollution levels but the US is still holding out because it seems to be more concerned about economic growth than pollution emissions.

\section{The Kyoto Mechanisms:}

Under the Kyoto Protocol agreement, the Annex B countries must meet their targets primarily through national measures. However, the Kyoto Protocol offers them an additional means of meeting their targets. They are:

- Emission Trading - known as the "Carbon Market",

- Clean Development Mechanism (CDM) and - Joint Implementation (J).

Emission Trading:

As set out in Article 17 of the Kyoto Protocol, emission trading allows those countries that have spare units of emission can sell these units to those countries that have exhausted their emission units, through the Climate Exchange. Carbon is now traded like any other commodity in the "Carbon Market"

\section{Trading Units in the carbon market:}

The emission units to be traded, each equal to one tonne of carbon dioxide, may be in the form of:

- A removal unit (RMU) on the basis of land use, land-use change and forestry (LULUCF) activities such as reforestation

An emission reduction unit (ERU) generated by a Joint Implementation project

A certified emission reductions (CERs) generated from a Clean Development Mechanism project activity.

\section{Clean Development Mechanism (CDM)}

Clean Development Mechanism (CDM), defined in Article 12 of the Kyoto Protocol, allows a country with an emission - reduction commitment under the Kyoto Protocol (Annex B Country) to implement an emissionreduction project in developing countries and in return gain the emission reduction credits (CERs) to meet its Kyoto targets, e.g. a rural electrification project using solar panels or the installation of more energy-efficient boilers.

\section{Joint Implementation (JI)}

The Joint Implementation mechanism, defined in Article 6 of the Kyoto Protocol, allows a country with an emission reduction commitment under the Kyoto Protocol (Annex B Country) to earn emission reduction units (ERUs) from an emission reduction/removal project in another Annex B country, to meet its Kyoto targets. A Joint Implementation project must provide a reduction in emissions by sources, or an enhancement of removals by sinks.

The Joint Implementation and Clean Development Mechanism are the two project-based mechanisms which feed the carbon market. Jl enables industrialized countries to carry out joint implementation projects with other developed countries, while the CDM involves investment in sustainable development projects, in developing countries, that reduce emissions of greenhouse gases addressed by the Kyoto Protocol. Table 1:

Greenhouse Gases addressed by the Kyoto Protocol And their global warming potential

\begin{tabular}{|c|l|l|l|}
\hline Sl. & \multicolumn{1}{|c|}{ Gas } & $\begin{array}{l}\text { Global } \\
\text { warming } \\
\text { potential }\end{array}$ & \multicolumn{1}{|c|}{$\begin{array}{l}\text { Atmospheric } \\
\text { life (years) }\end{array}$} \\
\hline 1 & $\mathrm{Co}_{2}$ - Carbon Dioxide & 1 & $5-200$ \\
\hline 2 & $\mathrm{CH}_{4}$ - Methane & 21 & 12 \\
\hline 3 & $\mathrm{~N}_{2} \mathrm{O}$ - Nitrous Oxide & 310 & 114 \\
\hline 4 & HFCs - Hydrofluorocarbons & $140-11700$ & $14-260$ \\
\hline 5 & PFCs - Perfluorocarbons & $560-9200$ & $10000-50000+$ \\
\hline 6 & Sf $_{6}$ - Sulpur hexafluoride & 23900 & 3200 \\
\hline
\end{tabular}

Source: UNDP - 2003

Of these, carbon dioxide $\left(\mathrm{CO}_{2}\right)$ is the most common because it is emitted by routine activities like burning fossil fuels for energy and transport. 
The road ahead:

World leaders met again in Bali, Indonesia, in December 2007, to consider the next phase after the end of the Kyoto Protocol (2012), which will deal with global strategies and policies for containing global pollution

India and Carbon Trading:

India is a Party to the United Nations Framework Convention on Climate Change (UNFCCC). In December 1997, India became a signatory to the Kyoto Protocol and ratified the same in August 2002, to fulfill the prerequisites for implementation of Clean Development Mechanism projects in India. The Government of India constituted the National Clean Development Mechanism Authority in 2003, for the purpose of protecting and improving the quality of environment in terms of Kyoto Protocol. The National Authority evaluates and approves CDM projects as per the guidelines of Designated Operational Entity authorized by CDM Executive Board and UNFCCC.

At present trading in carbon credits takes place in two stock exchanges -

$\square$ The Chicago Climate Exchange (CCX)

D The European Climate Exchange (ECX)

Multi Commodity Exchange of India Ltd. the country's leading commodity exchange, entered into a strategic alliance with Chicago Climate Exchange in September 2005 to initiate carbon trading in India. The tie-up would provide immense scope and opportunity for domestic suppliers to realize better prices for their carbon credits.

India's position in the international carbon market A comparative study:

\section{Methodology and Data Collection:}

The present study is based on both primary as well as secondary data. The primary data is collected through interaction with officials of Bhoruka Power Corporation Ltd. Bangalore. The secondary data is collected from journals, magazines and websites.

A comparative study is made with reference to the total and per capita carbon emissions; cost of greenhouse gas emissions; and registered project activities - by scope, scale and region, number of CERs - issued and expected average annual CERs by host party (select developing countries mainly China, India, Brazil, Republic of Korea and others).

Of the three Kyoto Mechanisms, Clean Development Mechanism is the only one available to a developing country like India for carbon trading. India is not obliged to cut emissions, as its energy consumption is low.

Table 2:

Total and Per Capita Carbon Emissions

\begin{tabular}{|c|l|c|c|c|}
\hline $\begin{array}{r}\text { SI. } \\
\text { No. }\end{array}$ & Country & $\begin{array}{c}\text { Total emission } \\
\text { (in billion tones) }\end{array}$ & $\begin{array}{c}\text { Per capita } \\
\text { emission } \\
\text { (in tones) }\end{array}$ & $\begin{array}{c}\text { Emission } \\
\text { growth rate } \\
\text { (in percentage) }\end{array}$ \\
\hline 1. & US & 6.0 & 21.4 & 1.7 \\
\hline 2. & China & 6.2 & 3.84 & 11.0 \\
\hline 3. & India & 1.34 & 1.2 & 6.0 \\
\hline
\end{tabular}

Source: Compiled by the author.

China, the US and India are the three world's largest polluters. India and China have no legally binding caps on their greenhouse gas emissions on the grounds that their per capita carbon emissions are the lowest among major economies. Their emissions are growing at 6 per cent \& 11 percent respectively as opposed to the US's 1.7 percent.

India's most polluting industry is coal based power generation, which supplies 53 per cent of India's total power $(77 \mathrm{GW})$ and emits 51 percent of its $\mathrm{CO}_{2}(638$ million tones) India's Thermal Power plants are $\mathbf{5 0}$ per cent more polluting than their global peers because most of them use cheap and old -world boilers.

In achieving compliance with quantified emission reduction commitments, a developed country would take up greenhouse gas reduction project activities in developing countries where the costs of greenhouse gas reduction project activities are usually much lower, with the purpose to assist developing countries in achieving Sustainable Development and in contributing to the ultimate object of the Convention. 
Table 3:

Cost of Greenhouse Gas emission reduction

\begin{tabular}{|l|l|}
\hline Country & US\$ per tonne of carbon \\
\hline Japan & 400 \\
\hline USA & 175 \\
\hline India & 25 \\
\hline
\end{tabular}

Source: E \& Y Report on CDM project Development, February 7, 2005.

Table 3 shows that cost of emission reduction of Japan and USA, is much higher than that of India. Thus, transferring clean technology to a developing country like India offers a cost effective solution to developed nations.

Table 4:

\section{Registered Project Activities by host party}

\begin{tabular}{|c|l|l|l|}
\hline St.No. & Country & Number of projects & Percentage of total \\
\hline 1. & India & 378 & 29.44 \\
\hline 2. & China & 340 & 26.48 \\
\hline 3. & Brazil & 146 & 11.37 \\
\hline 4. & Mexico & 110 & 8.57 \\
\hline 5. & Malaysia & 35 & 2.73 \\
\hline 6. & Chile & 27 & 2.10 \\
\hline 7. & Others & 248 & 19.31 \\
\hline & Total & 1284 & 100.00 \\
\hline
\end{tabular}

Source: Compiled by the author

Registered project activities by host party, Total :1,284

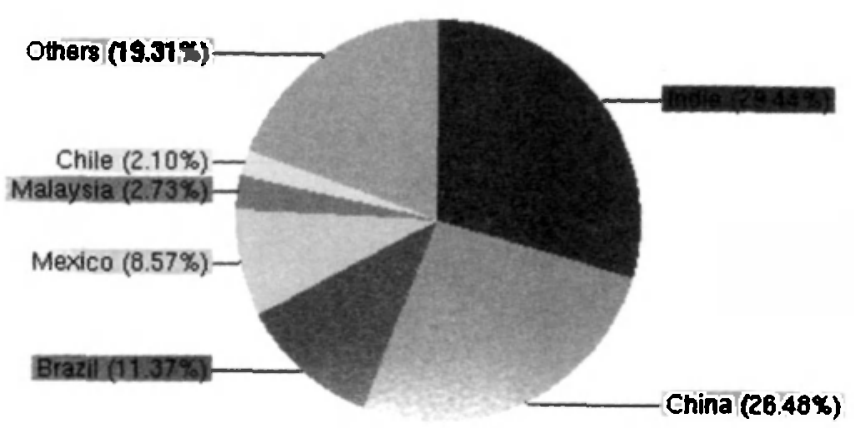

http://cdm unfccc.int(c)23.12.2008 14:53
India leads the registered project activities with 29.44 percent, followed by China with 26.48 per cent and Brazil with 11.37 per cent to the total projects registered of 1284. Among the total registered projects 707 are of large scale and 577 of small scale projects.

Table 5:

Distribution of registered project activities by sectoral scope

\begin{tabular}{|c|l|c|c|}
\hline Sl. & \multicolumn{1}{|c|}{ Sectoral Scope } & $\begin{array}{c}\text { Registered } \\
\text { projects }\end{array}$ & $\begin{array}{c}\text { Percentage } \\
\text { of total }\end{array}$ \\
\hline 1 & $\begin{array}{l}\text { Energy industries (renewable } \\
\text { non-renewable sources }\end{array}$ & 924 & 57.00 \\
\hline 2 & Energy distribution & 0 & 0.00 \\
\hline 3 & Energy demand & 18 & 1.11 \\
\hline 4 & Manufacturing industries & 83 & 5.12 \\
\hline 5 & Chemical industries & 41 & 2.43 \\
\hline 6 & Construction & 0 & 0.00 \\
\hline 7 & Transport & 2 & 0.12 \\
\hline 8 & Mining / mineral production & 14 & 0.86 \\
\hline 9 & Metal production & 2 & 0.12 \\
\hline 10 & $\begin{array}{l}\text { Fugitive emissions from fuels } \\
\text { (solid, oil \& gas) }\end{array}$ & 120 & 7.40 \\
\hline 11 & $\begin{array}{l}\text { Fugitive emissions from } \\
\text { production \& consumption } \\
\text { of halocarbons and sulphur } \\
\text { hexafluoride }\end{array}$ & 18 & 1.11 \\
\hline 12 & Solvent use & 1284 & 100.00 \\
\hline 13 & Waste handling and disposal & 307 & 18.94 \\
\hline 14 & Afforestation and reforestation & 1 & 0.06 \\
\hline 15 & Agriculture & 15 & 5.61 \\
\hline & Total & & 0.00 \\
\hline
\end{tabular}

Source: Compiled by the author

* Note that a project activity can be linked to more than one sectoral scope 


\section{Distribution of registered project activities by scope}

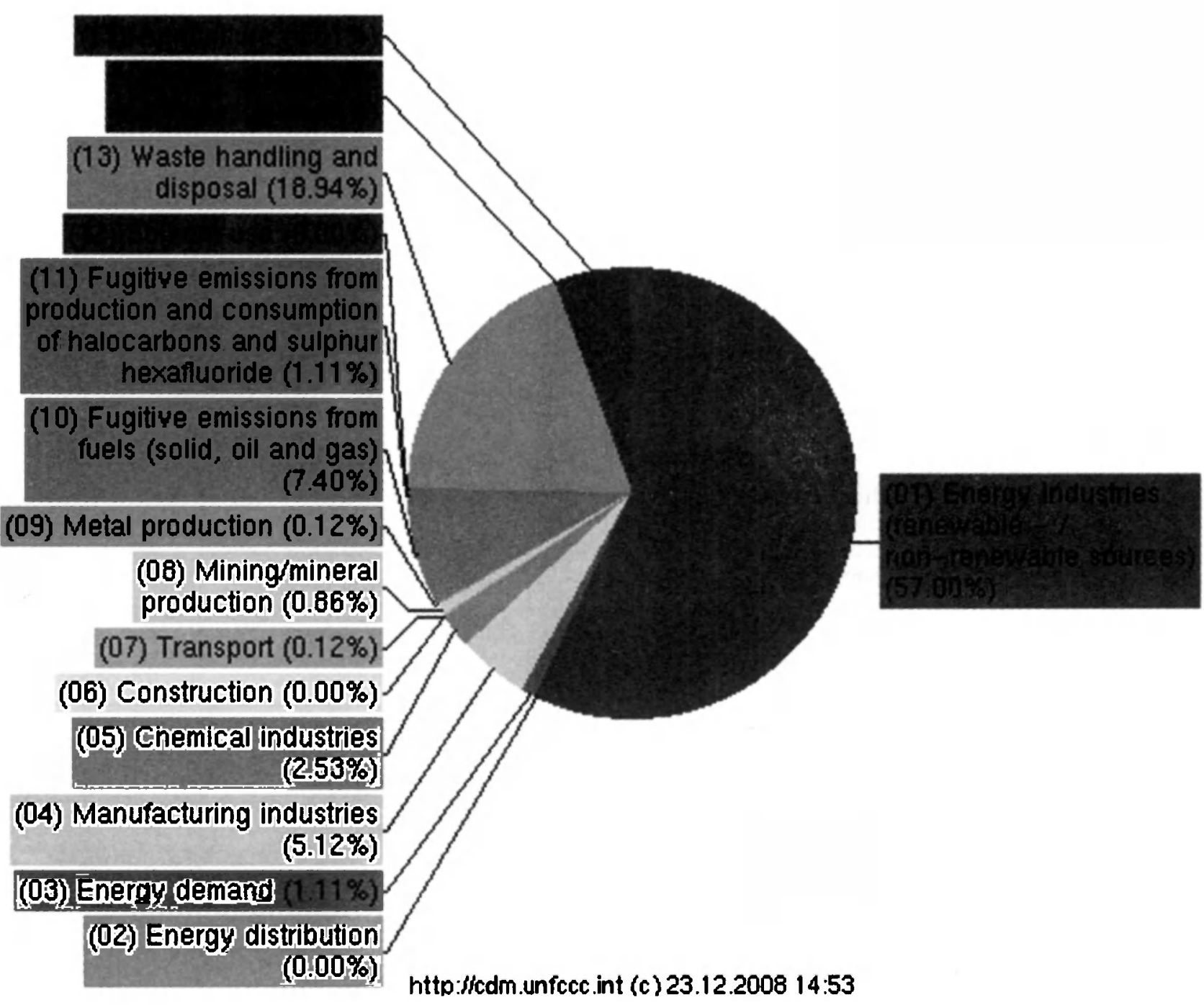

Among the registered projects by sectoral scope, projects related to energy industries (renewable/non-renewable sources) are the most preferred project types by the CDM participants $(57.00 \%)$, followed by waste handling and disposal (18.94\%). Projects related to solvent use and energy distribution are not the preferred ones $(0.00 \%)$ Table 6:

Registered Projects by Region

\begin{tabular}{|l|l|c|c|}
\hline S1.No. & Region & Number of projects & Percentage to total \\
\hline 1. & NA1 - Africa & 28 & 2.18 \\
\hline 2. & NA1 - Asia and the Pacific & 860 & 66.98 \\
\hline 3. & NA1 - Other & 8 & 0.62 \\
\hline 4. & $\begin{array}{l}\text { NA1 - Latin America and the } \\
\text { Caribbean }\end{array}$ & 388 & 30.22 \\
\hline & Total & $\mathbf{1 2 8 4}$ & $\mathbf{1 0 0 . 0 0}$ \\
\hline
\end{tabular}

Source: Compiled by the author. (Note : NA1 - Non-Annex 1 parties) 


\section{Registered projects by region. Total 1284}

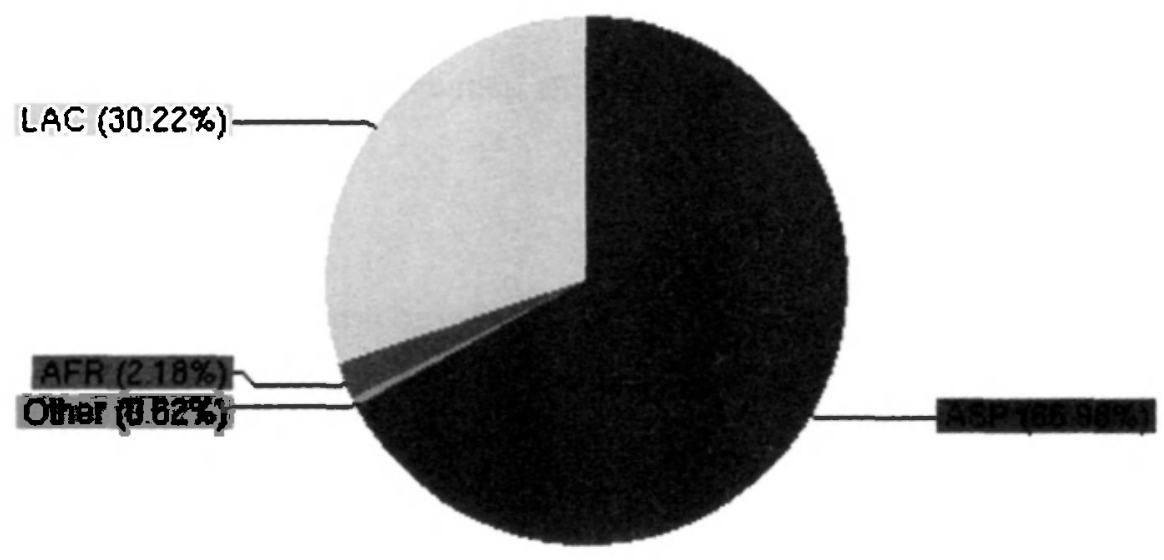

htto:Ilcdm unfccc.int (c) 23.12 .200814 .54

Region-wise distribution of registered projects shows that more than two - third of the registered projects are from Asia and the Pacific region(ASP), followed by Latin America and Caribbean(LAC), 30.22\%.

\section{Table 7:}

\section{CERs issued by host party}

\begin{tabular}{|l|l|l|l|}
\hline Sl.No. & Country & CERs issued & Percentage to total \\
\hline 1. & China & $96,232,749$ & 40.80 \\
\hline 2 & India & $54,182,398$ & 22.97 \\
\hline 3. & Republic of Korea & $35,471,714$ & 15.04 \\
\hline 4. & Brazil & $28,373,227$ & 12.03 \\
\hline 5. & Mexico & $5,037,242$ & 2.14 \\
\hline 6. & Viet Nam & $4,486,500$ & 1.90 \\
\hline 7 & Others & $12,103,837$ & 5.13 \\
\hline & Total & $\mathbf{2 3 5 , 8 8 7 , 9 6 7}$ & $\mathbf{1 0 0 . 0 0}$ \\
\hline
\end{tabular}

Source: Compiled by the author

CERs issued by host party. Total $235,887,967$

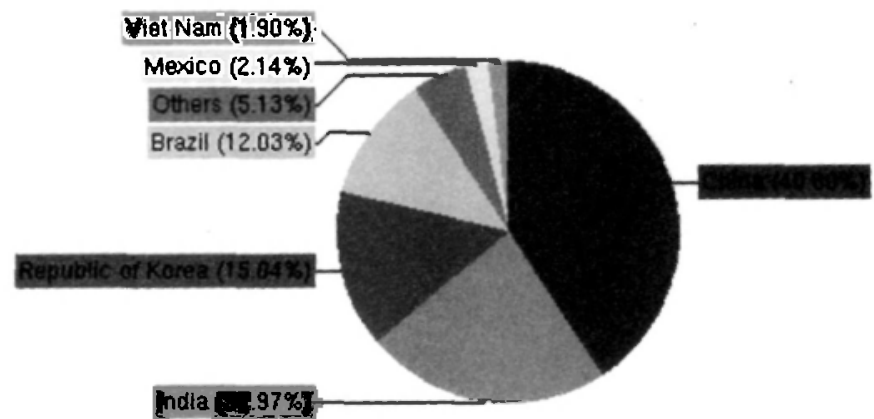

http/kadm.unfece int (c) 22.12200816 .53 
Though India tops the list of registered projects with $29.44 \%$, followed by China with $26.48 \%$, but with regard to CERs issued by host party, India ranks second $(22.97 \%)$ to China with $\mathbf{4 0 . 8 0 \%}$. Brazil ranks third with $12.03 \%$ of the total CERs issued. This shows the per project emission reduction is less in India than that of China.

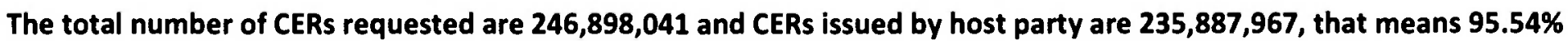
of the total CERs requested have been issued by host party.

Table 8:

Expected average annual CERs from registered projects by host party

\begin{tabular}{|l|l|c|l|}
\hline Sl.No. & Country & Average Annual CERs & Percentage to total \\
\hline 1. & China & $130,622,589$ & 54.02 \\
\hline 2. & India & $32,484,553$ & 13.43 \\
\hline 3. & Brazil & $19,515,656$ & 8.07 \\
\hline 4. & Republic of Korea & $14,599,555$ & 6.04 \\
\hline 5. & Mexico & $7,985,793$ & 3.30 \\
\hline 6. & Chile & $4,336,652$ & 1.79 \\
\hline 7. & Argentina & $4,121,351$ & 1.70 \\
\hline 8. & Indonesia & $3,153,610$ & 1.30 \\
\hline 9. & Malaysia & $2,681,453$ & 1.11 \\
\hline 10. & South Africa & $2,557,984$ & 1.06 \\
\hline 12. & Qatar & $2,499,649$ & 1.03 \\
\hline 13. & Others & $17,265,802$ & 7.14 \\
\hline & Total & $\mathbf{2 4 1 , 8 1 7 , 9 5 5}$ & $\mathbf{1 0 0 . 0 0}$ \\
\hline
\end{tabular}

Source: Compiled by the author

Explected average annual CERs from registered projects by host party. Total: $241,817,955$

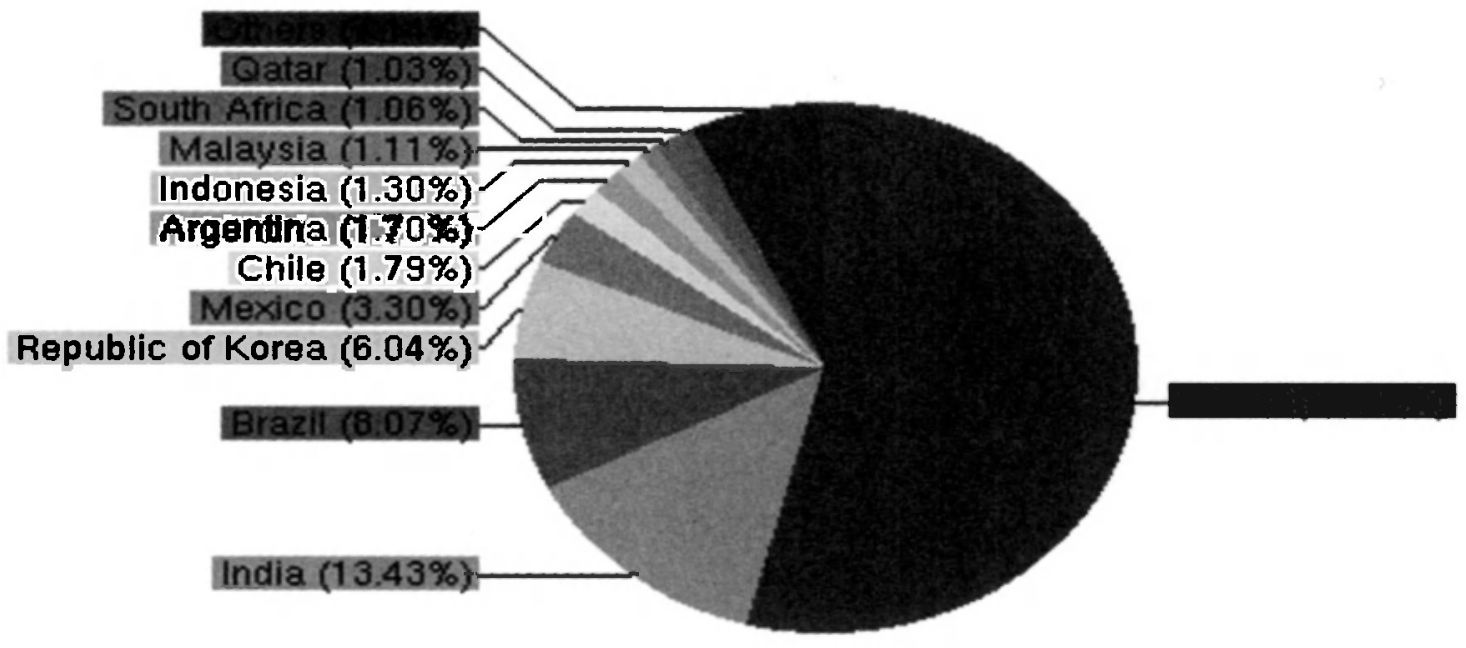

http://cdm.unfccc.int (c) 23.12.2008 14:53 
The expected average annual CERs from registered projects by China with $54.02 \%$, followed by India with $13.43 \%$, four times more than that of India, shows the China's ability to generate more CERs by reducing more and more greenhouse gas emissions. It is also found that Indian CDM projects are smaller than that of China hence expected average annual CERs is much lower than that of China.

\section{Findings of the Study:}

1. The latest World Bank figures show that India has emerged as a big player in the carbon trading market, ranking as the second-largest seller of carbon credits in the global market

2. India has 378 carbon credit projects in the pipeline and tops the world list of CDM venture followed by China 340 and Brazil 146.

3. India's share in expected average annual CERs is only $13.43 \%$, as compared with China's gigantic $54.02 \%$. Low-hassle factor helps China dominate carbon credit market.

4. Many Indian companies are registered with CDM Executive Board for carbon credits. To name a few Wind turbine giant Suzlon Energy, solar power pioneer Tata BP Solar, Gujarat Fluoro Chemicals Ltd., Torrent Power Ltd., Jindal Steel works Ltd., Bhoruka Power Corporation Ltd., Steel Authority of India Ltd., and many other power-generating companies are either switching to cleaner fuels or to renewable energy such as hydro, solar or wind, spurred by the knowledge that they will make money from it.

5. During 2007, Indian companies made \$US 300 million by selling CERs.

6. By 2012, India's earnings are estimated to jump to \$US 3.6 billion.

7. The World Bank estimates that the potential for India from carbon trade is around \$US 100 billion annually by 2010 .

8. In the new regime, the country could emerge as one of the largest beneficiaries accounting for 25 percent of the total world carbon trade, says a recent World Bank Report.

9. Japan is the largest buyer of carbon credit while Chine, India and Brazil are amongst the largest suppliers of carbon credit.
10. A recent study in December 2008, says prices of Carbon Credits have crashed to Euro 14 per tonne from a peak of Euro 20 two months ago, due to multiple reasons, mainly economic slow down in many developed countries and fall in crude oil price to below $\$ 40$ per barrel from a record high of $\$ 147$ per barrel in July 11, 2008.

11. India's quantum of unsold CERs (over 42 million) currently accounts for more than $40 \%$ of the world's unsold CERs.

\section{Suggestions:}

(2) The main objective of UNFCCC and the Kyoto Protocol to reduce greenhouse gas emission must be kept in mind by the buyers and sellers of carbon credit. If the whole trade becomes too profit-oriented, then it will lose its central focus.

(8) The carbon market is still in its infancy stage, it needs to become institutionally and geographically stronger which will result in fairer and transparent trading system.

(2) Even though enough carbon credits are being generated and transacted under the Kyoto Protocol, there are currently no international accounting standards on emissions. The accounting procedures and legal aspects of carbon trading need to be given a better framework and require standardization.

(2) India needs to enhance its expected average annual CERs from registered projects on par with that of China by increasing the size of its CMD projects.

(2) Carbon Credit is a complex commodity, wherein the sellers are in India and the buyers abroad. The need for a custodian with a multinational presence is essential to ensure timely delivery of the commodity to the buyers.

\section{Conclusion:}

India, by ratifying the Kyoto Protocol, supported its participation in the international carbon market. India's future as a net supplier of carbon credits is vibrant. The growing enthusiasm from all sectors, to curb pollution levels and to avail benefits of CDM activities, has made India a viable destination for foreign investments and latest clean technology transfers. The future of carbon trading depends on how technology, policy and the international carbon market work together in the unforeseen future. 


\section{REFERENCES:}

Prices of carbon credit crash: Namrata Singh, The Times of India, December 2008

The Green Trade: Pierre Mario Fitter \& Alexis Ringwald, Business World, 22 September 2008

Carbon Emissions - Accounting for Carbon, Malcon Mc Gready. Financial Reporting July 2008

Global Warming and Corporate Disclosures in India : Bikki Jaggi \& Martin Freedman. Indian Accounting Review, June 2008

Carbon Credit - Tool for Global Environment Protection: G.Rajandran, Executive Chartered Secretary, February 2008.

Carbon Trading in India - An Insider's view: Radha Purswani, ICFAl Journal Treasury Management, May 2008 Carbon Credit and India's Strategic Position: Janki Mistry \& Pikesh J Gandhi, ICFAl Journal of Environmental Economics, 2007

Techno-Economics of CDM - The Mechanism and a Case Study on Steel Industry: Subir Bhattacharya, R C Khowala and K D Choudhury, ICFAl Journal of Environmental Economics Vol. V, No,3, 2007

Emission Trading and Carbon Credits - An overview: Ketan Madia, Executive Chartered Secretary, October 2006 Accounting and Taxation Aspects of Carbon Trading: Sanja K Agrwal, CA, The Chartered Accountant, October 2006 Web sites- google.com. yaahoo.com., unfccc.int., cdproject.net, cdmindia.nic.in, ieta.org telegraphindia.com., livemint.com. 